*Advogado e historiador. Bacharel, mestre e doutor pela Universidade de São Paulo - USP, com bolsa de doutorado SWE do $\mathrm{CNPq}$ na Université de Bordeaux III (Michel de Montaigne). Pós-doutorado, com bolsa da FAPESP, na Université de Paris III (SorbonneNouvelle) e pós-doutorado, com bolsa da CAPES, na Université de Limoges (CRIDEAU).E-mail: profmialhe@hotmail.com

**Advogado, Especialista em Direito Administrativo pela Pontifícia Universidade Católica de São Paulo, Especialista em Direito Tributário pela Faculdade Damásio de Jesus, Mestrando em Direito pela UNIMEP - Universidade Metodista de Piracicaba, Professor de Direito na FADITU - Faculdade de Direito de Itu.E-mail: thiago.rigamonti@ gmail.com

\section{As Alterações na Lei de Introdução Às Normas Do Direito Brasileiro e SEU Influxo no Direito ADMinistrativo}

\author{
The AmENDMENTS IN THE LAW OF INTRODUCTION TO \\ THE Standards of BraZILIAN LaW AND ITS INFLUX ON \\ ADMINISTRATIVE LAW
}

\section{Jorge Luís Mialhe* Thiago Reis Augusto Rigamonti**}

Como citar: MIALHE, Jorge Luís; RIGAMONTI, Thiago Reis Augusto. As alterações na Lei de Introdução às Normas Do Direito Brasileiro e seu influxo no Direito Administrativo. Revista do Direito Público, Londrina, v. 16, n. 1, p. 97-118, abr. 2021. DOI: $10.5433 / 24157-108104-1.2021 v 16 n 1 p$. 97. ISSN: $1980-511 \mathrm{X}$

Resumo: A Lei de Introdução às Normas do Direito Brasileiro (LINDB) é reconhecida enquanto a norma das normas, pois que confere diretrizes e balizas relevantes relacionadas à vigência, eficácia e interpretação dos diplomas normativos no sistema jurídico nacional, inclusive no que atine às suas fontes e técnicas de integração, delimitando a aplicação de normas no tempo e no espaço. Foi relevante e recentemente contemplada com acréscimos provenientes da Lei Federal n. ${ }^{\circ}$ 13.655/2018, que, promulgada, acresceu à LINDB dispositivos precipuamente relacionados à aplicação e interpretação de normas incidentes em Direito Público, especialmente no que se relaciona ao exercício do controle da Administração Pública - e de seus agentes - pelos órgãos detentores de tais competências. Este trabalho, sob baliza doutrinária, busca enfatizar as alterações promovidas, sob o método dedutivo.

Palavras-chave: Lei de introdução às normas do direito brasileiro. Influxo em direito administrativo repressivo. Controle da administração pública.

Abstract: The Introduction to the Standards of Brazilian Law (in Portuguese Lei de Introdução às Normas do Direito Brasileiro or LINDB) is recognized as the Standard of the Standards, because it provides relevant guidelines and landmarks related to the validity, effectiveness and interpretation of the legislative instrument in the national juridical system, including about it, sources and integration technics, limiting application of the legal standards 
in time and space. It was relevantly and recently contemplated with additions included by the Federal Law no $13.655 / 2018$, which, after promulgated, added to the LINDB legal devices mainly related to the application and interpretation of legal standards of Public Law, especially in the control of the Public Administration - and its public officials - by the organs which possess these competences. The present master's degree's work, under the landmarks of doctrine and jurisprudence, aims to emphasize the changes promoted, using the deductive method.

Keywords: The Introduction to the Standards of Brazilian Law. Influx in Repressive Administrative Law. Control in Public Administration. 
A Lei de Introdução às Normas do Direito Brasileiro (Decreto-Lei n. ${ }^{\circ}$ 4.657/1942) percebeu recentemente a mais relevante modificação já em si procedida, incluindo nela diversos dispositivos normativos que se relacionam precipuamente à interpretação e aplicação de normas no ambiente jurídico-administrativo (BRASIL, 1942).

As alterações promovidas em aludido diploma legislativo - que se consubstancia, sem margem de erro, em uma das principais leis que informam o direito nacional -, muito delimitando regras de direito público, reproduzem inequívoco influxo em decisões administrativas e judiciais que se relacionem ao controle da atuação da Administração Pública e de seus agentes.

Considere-se, com vistas a se estimar a relevância de qualquer dispositivo normativo hábil a refletir no controle da gestão da res publica, que os órgãos comumente dotados de competência para tal mister fiscalizatório possuem matriz constitucional de relevo ${ }^{1}$, tampouco sendo de se ignorar que o direito ao patrimônio público e a sua gestão sóbria, eficiente e regular se compreendem enquanto direitos difusos cuja titularidade repousa na indeterminada coletividade social.

Convém assinalar que as modificações da LINDB foram introduzidas através da Lei Federal n. ${ }^{\circ}$ 13.655/2018 (BRASIL, 2018a), cujo processo legislativo² foi marcado por ressalvas e discordâncias por parte de órgãos de controle (BRASIL, 2018b), prostrando-se, não obstante, defendida por juristas (MARQUES NETO et al., 2018) e pelos órgãos técnicos do Poder Legislativo (BRASIL, 2017), sendo, ao fim, promulgada, de certo que suas consequências se incluem ao centro de notáveis esforços exegéticos³.

Recentemente se deu sua regulamentação através do Decreto Federal n. ${ }^{\circ}$ 9.830/2019, de 10 de junho de 2019, cujas disposições não devem ser olvidadas (BRASIL, 2019).

Nas próximas seções se desenvolverá a apreciação das específicas introduções promovidas pela Lei Federal n. ${ }^{\circ}$ 13.655/2018 (BRASIL, 2018a) e pela norma regulamentar, sob o método dedutivo.

\section{DO ARTIGO 20 DA LEI DE INTRODUÇÃO ÀS NORMAS DO DIREITO BRASILEIRO E DA DELIMITAÇÃO DE JULGAMENTOS BALIZADOS EM PRINCÍPIOS OU CONCEITOS JURÍDICOS INDETERMINADOS}

Anota-se, preliminarmente, que a Lei de Introdução às Normas do Direito Brasileiro se consubstancia em diploma normativo voltado a informar a vigência e eficácia das normas no sistema jurídico nacional, além de trazer fontes normativas como técnicas de sua integração e de interpretação, daí afirmar Gonçalves (2012, p. 48-49) ser ela "conjunto de normas sobre normas", que se dirige "a todos os ramos do direito, salvo naquilo que for regulado de forma diferente na legislação específica."

Possui as essenciais funções de regular a vigência e a eficácia das normas jurídicas (arts. $1^{\circ}$ e $2^{\circ}$ ),

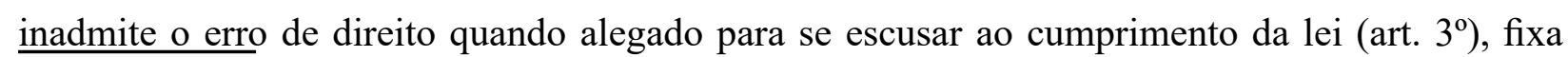

1 Vide, v.g., artigos 70 a 75 da Constituição Federal no que se relaciona às competências dos Tribunais de Contas e arts. 127 a 130 quanto às do Ministério Público (BRASIL, 1988, p. 38-39, 59-61).

2 O projeto legislativo é de autoria do Senador Antonio Anastasia (PSDB/MG).

3 Mencionem-se as reuniões e debates públicos procedidos no âmbito do TCU, sendo digna de nota a visualização do primeiro encontro por mais de 1,5 milhões de usuários ao vivo (BRASIL, 2018d, grifo nosso). 
mecanismos de integração das normas jurídicas (art. $4^{\circ}$ ), estabelece a equidade e a socialidade enquanto critérios de hermenêutica (art. $5^{\circ}$ ), delimita soluções a conflitos da lei no tempo (art. $6^{\circ}$ ) e contém normas de direito internacional privado (arts. $7^{\circ}$ a 19) (GONÇALVES, 2012, p. 49).

A partir da promulgação da Lei Federal n. ${ }^{0}$ 13.655/2018 (BRASIL, 2018a), passou a LINDB a contar com os artigos 20 a 30, cujos dispositivos produzem influxo no direito público repressivo, notadamente face à atuação dos órgãos de controle (Tribunais de Contas, sistemas de controle interno - e externo - e Ministério Público). Inicia-se, e já por relevante, com o seu art. 20 (mais polêmico dos dispositivos):

Art. 20. Nas esferas administrativa, controladora e judicial, não se decidirá com base em valores jurídicos abstratos sem que sejam consideradas as consequências práticas da decisão.

Parágrafo único. A motivação demonstrará a necessidade e a adequação da medida imposta ou da invalidação de ato, contrato, ajuste, processo ou norma administrativa, inclusive em face das possíveis alternativas (BRASIL, 2018a).

Tem-se como oportuno precisar, a priori, que o caput do dispositivo, ao se valer da intitulação "valores jurídicos abstratos", está a mencionar o que, na concepção jurídica, ter-se-ia enquanto "princípios". Reforça esta assertiva a anotação de que o Decreto regulamentador dos arts. 20 ao 30 da LINDB (Decreto Federal n. ${ }^{\circ}$ 9.830/2019) delimita que "consideram-se valores jurídicos abstratos aqueles previstos em normas jurídicas com alto grau de indeterminação e abstração.” (art. $3^{\circ}, \S 1^{\circ}$ ) (BRASIL, 2019).

Isto pois os princípios são, por evidente, valores, mormente porque exprimem a síntese de valores sociais que então passam a ser reconhecidos pelo Direito, juridicizando-os através do processo político democrático (MARTINS, 2010, p. 18).

Tratando-se, pois, de princípios, reconhecidos estes são, na doutrina de Mello (2019, p. 54), enquanto mandamentos nucleares de um sistema, daí possuírem por precípua atribuição o influxo interpretativo (SILVA, 2013, p. 47) tanto ao legislador quanto ao intérprete, constituindo-se de valores a que o sistema deve se esforçar para atender ao máximo (BULOS, 2012, p. 47).

Possuem, não obstante, induvidoso caráter de abstratividade, visto que posta a amplitude deles, neles não se vislumbrará caráter absoluto (BARROSO, 2015, p. 64-65).

Daí bem se amoldam à concepção e exegese dos aludidos "valores jurídicos abstratos" (art. 20, LINDB) as lições de Alexy (2012, p. 90-91 e 93-94), ao determinar que as normas jurídicas se dividiriam em princípios e regras, os primeiros concebidos enquanto "mandamentos de otimização", suscetíveis de "ponderação" conforme o caso concreto:

As colisões entre princípios devem ser solucionadas de forma completamente diversa. Se dois princípios colidem - o que ocorre, por exemplo, quando algo é proibido de acordo com um princípio e, de acordo com o outro, permitido -, um dos princípios terá que ceder. Isso não significa, contudo, nem que o princípio cedente deva ser declarado inválido, nem que nele deverá ser introduzida uma cláusula de exceção. Na verdade, o que ocorre é de que um dos princípios tem 
precedência em face do outro sob determinadas condições. Sob outras condições a questão da precedência pode ser resolvida de forma oposta. Isso é o que se quer dizer quando se afirma que, nos casos concretos, os princípios têm pesos diferentes e que os princípios com o maior peso têm precedência. Conflitos entre regras ocorrem na dimensão da validade, enquanto as colisões entre princípios - visto que só princípios válidos podem colidir - ocorrem, para além dessa dimensão, na dimensão do peso (ALEXY, 2012, p. 93-94).

Sorte distinta socorrem as regras, as quais sofrem, à luz do quanto leciona Ávila (2009, p. 78-79), o dito juízo da subsunção, técnica esta que pela máxima do silogismo, atrai solução única pela validade ou invalidade da espécie face a regra normativa.

De fato, embora não se ignore a importância axiológica dos princípios na informação do Direito e de sua aplicação, não se deve olvidar que o Juízo procedido por órgãos de controle são sobretudo de validade e regularidade dos atos administrativos sub examine, sendo bem delimitadas as hipóteses em que atuam de forma consultiva.

Isto dito, considerando-se que os juízos sobre determinada atuação estatal, quando por sua irregularidade, geralmente lhes proclama a invalidade e decorrentes apurações, sancionamentos e ressarcimentos, a princípio se reconhece se prostrar um tanto quanto razoável ${ }^{4}$ que eventual decisão lastreada em princípios jurídicos se dê apenas e tão somente em se considerando as "consequências práticas da decisão" (art. 20, caput, LINDB), bem como a necessidade e a adequação da medida

4 "Como bem salienta Willis Santiago Guerra Filho, na Inglaterra fala-se em princípio da irrazoabilidade e não em princípio da razoabilidade. [...] E esse teste da irrazoabilidade, conhecido também como teste Wednesbury, implica tão somente rejeitar atos que sejam excepcionalmente irrazoáveis. Na fórmula clássica da decisão Wednesbury: 'se uma decisão [...] é de tal forma irrazoável, que nenhuma autoridade razoável a tomaria, então pode a corte intervir'. Percebe-se, portanto, que o teste sobre a irrazoabilidade é muito menos intenso do que os testes que a regra da proporcionalidade exige, destinando-se meramente a afastar atos absurdamente irrazoáveis." (SILVA, 2012, p. 29).

“A noção do 'razoável' ultrapassa a do 'racional'. Em verdade, a razoabilidade torna-se critério de aferição da legitimidade de decisões administrativas que não se mantém perante o direito, por serem insuficientes os critérios de estrita racionalidade para afirmar sua validade. A razoabilidade é critério avaliativo do exercício da discrição, quando da aplicação da lei por meio de uma estimativa valorativa das circunstâncias empíricas, operação esta que não se cinge às regras racionais da lógica dedutiva, mas requer o manuseio de uma 'lógica' própria do direito, voltado como está para a implantação e manutenção dos valores consagrados em seu seio.

[...] Há um padrão de 'conduta razoável' para cada atuação discricionária da Administração. É que a razoabilidade responde à tendência no direito administrativo de configurar materialmente a noção de competência, emergente tão-somente com a compostura que lhe der o caso concreto. Logo, somente perante a fisionomia objetiva deste é o possível examinar se a atividade administrativa, a título de perseguir o interesse público concreto, afasta-se do standard de razoabilidade imposto pelo direito positivo.” (OLIVEIRA, 2008, p. 31-32). 
imposta, inclusive face eventuais alternativas incidentes (ou não incidentes), a teor do parágrafo único do aludido art. 20.

Não nasce com o caput do art. 20 a crítica a que julgadores procedam, com relativa facilidade, a decidir da maneira que, contemporaneamente, pareça-lhes porventura mais adequado ter se decidido $^{5}$ no passado, porém o fazendo sem a detença à ponderação procedida legitimamente por aquele que, à época, detinha a competência para tal ${ }^{6}$.

É o que o Ministro do Supremo Tribunal Federal Luís Roberto Barroso (BRASIL, 2020, p. 14) denominou recentemente de "comentarista de videoteipe": "quando se vai julgar o que passou, age-se como um 'comentarista de videoteipe", pois passado o tempo, depois que tudo aconteceu, quando se pode olhar os fatos à distância, "percebem-se muitas coisas que, quando se está ali no calor do momento, não se é capaz de perceber".

Em se tratando de competência originária doutro Poder ou órgão constituído, sem proceder à mínima redução das competências de quaisquer órgãos de controle, pode se afirmar que o cotejo do mérito da decisão matriz sempre será, em rigor, minimamente cautelosa, merecendo destaque os excertos de Mello (2019) e Meirelles (2012):

O campo de apreciação meramente subjetiva - seja por conter-se no interior das significações efetivamente possíveis de um conceito legal fluido e impreciso, seja por dizer com a simples conveniência ou oportunidade de um ato - permanece exclusivo do administrador e indevassável pelo juiz, sem o quê haveria substituição de um pelo outro, a dizer, invasão de funções que se poria às testilhas com o próprio princípio da independência dos Poderes, consagrado no art. $2^{\circ}$ da Lei Maior (MELLO, 2019, p. 1.051).

O que o Judiciário não pode é ir além do exame de legalidade, para emitir um juízo de mérito sobre os atos da Administração [...] A competência do Judiciário para a revisão de atos administrativos restringe-se ao controle da legalidade e da legitimidade do ato impugnado. Por legalidade entende-se a conformidade do ato com a norma que o rege; por legitimidade entende-se a conformidade com os princípios básicos da Administração Pública, em especial os do interesse público, da moralidade, da finalidade e da razoabilidade, indissociáveis de toda atividade pública (MEIRELLES, 2012, p. 790).

5 “"...] O Ministro João Otávio Noronha, presidente do Superior Tribunal de Justiça, foi enfático e não se furtou a dar exemplos e nomes [...] Noronha ressaltou que a estabilidade e vitaliciedade dos juízes são fatores fundamentais que devem ser preservados. Porém, não são armas das quais o magistrado pode se valer para impor sua visão de mundo. [...] 'O Judiciário agora zela pela moralidade formal, o que é uma deturpação da função do juiz. Tem juiz que determina que dinheiro apreendido seja repassado para determinado local. Isso não é coisa de juiz! Quem defende princípios constitucionais, como os ministros Gilmar Mendes e Ricardo Lewandowski, é vaiado na rua. Mas a decisão que determinou que o Sergio Cabral fosse acorrentado feito um animal sem motivo não tem pai. Decisão arbitrária não tem pai [...].” (MARTINES, 2018).

6 "Um sistema jurídico não é mau nem bom pelo fato de, em seus processos, princípios serem usados com muita frequência. O problema não está neles, mas na comodidade que podem oferecer para os espertos e para os preguiçosos. O oportunista, cujo interesse é adiar eternamente o pagamento de suas dívidas, invoca em juízo apenas o princípio do acesso à jurisdição e pede para não pagar, até o fim do processo principal: 'Negar a liminar' - diz ele - 'é cassar meu direito à Justiça'. É um esperto, com um argumento cômodo, ocultando a fragilidade de sua pretensão de mérito. $\mathrm{O}$ juiz que não queira o trabalho de analisar a plausibilidade do direito de fundo pode simplesmente aceitar o tal princípio e conceder a liminar ou invocar o princípio da obrigatoriedade dos contratos e negá-la. É um preguiçoso, usando fundamentos fáceis para esconder a superficialidade de sua decisão. Espertos e preguiçosos sempre existirão: o mal é que sua esperteza fique oculta, por conseguirem iludir os espectadores com truques de mágica - com a simples declaração de princípios. Para que, no debate jurídico, os princípios não sirvam como armas de espertos e preguiçosos é preciso impor, a quem os emprega, os ônus que lhes são inerentes”. (SUNDFELD, 2014, p. 215). 
Ambos os citados autores lecionam, então, no sentido de que é ao administrador - quando a competência a este título lhe seja dada pela lei - o juízo primário quanto aos critérios de oportunidade e conveniência do ato, devendo o controlador se atentar a não desfazer tal atribuição.

Se, mesmo assim, a hipótese for considerada pelo intérprete enquanto de possível deliberação por si - por considerar se submeter às suas legítimas competências de controle -, vislumbra-se como medida de esmero - quiçá obrigatória - que o faça a considerar a adequação e a necessidade da decisão a ser procedida, além das alternativas suscitadas no processo ou que, porventura, sejam notórias que infirmem ou que denotem a pertinência do quanto levado a efeito pelo gestor cujo ato administrativo se prostra a crivo.

Suscite-se, por oportuno, que as terminologias "adequação" e "necessidade" incorporadas no parágrafo único do art. 20 da LINDB, $\S 3^{\circ}$ do art. $3^{\circ}$ e $\S 2^{\circ}$ do art. $4^{\circ}$ do Decreto Federal n. ${ }^{\circ}$ 9.830/2019 nada mais são do que representativas das elucidações doutrinárias acerca do princípio da proporcionalidade, cujo influxo geral nas decisões de controle deixa de ser valorativo e passa a ser considerado juridicizado (BRASIL, 2019).

Isto pois o princípio da proporcionalidade é "entendido como um mandamento de otimização do respeito máximo a todo direito fundamental, em situação de conflito com outro (s), na medida do jurídico e faticamente possível" (GUERRA FILHO, 2007, p. 88-89), sendo decomposto em três elementos a serem observados face o caso concreto: a "adequação", a "necessidade" e a "proporcionalidade em sentido estrito", sendo o primeiro (adequação) a possibilidade de atingimento do fim pelo meio, o segundo (necessidade) a observância quanto à inexistência doutro meio menos gravoso hábil à satisfação do fim, e o terceiro (proporcionalidade em sentido estrito) enquanto signo de ponderação "se o meio utilizado é ou não desproporcionado em relação ao fim", isto é, reflete o "pesar as desvantagens dos meios em relação às vantagens do fim.” (MELLO, 2019, p. 114).

Há de se pontuar, mormente para a boa apreciação dialética do dispositivo normativo em epígrafe, as ressalvas relevantes procedidas, pois, pela Procuradoria Geral da República através da sobredita Nota Técnica Conjunta n. ${ }^{\circ}$ 01/2018 (BRASIL, 2018b, p. 4), durante o trâmite do projeto legislativo que culminou no texto promulgado (PL n. ${ }^{\circ} 7.448 / 2017$ ), ao anotar que:

[...] O dispositivo claramente desprestigia a prolação de decisão, inclusive judicial, com base em princípios. Impõe, ainda, que, caso assim o seja, considere as consequências práticas dela advindas. Ora, negar a possibilidade de decisão baseada em princípios é recusar densidade normativa dessa fonte do direito.

[...] O dispositivo, na redação apresentada, é bastante amplo, e dá abertura, inclusive, para que seja invocado mesmo nos casos de decisões judiciais que não tenham por objeto o controle de ato administrativo. Entretanto, mesmo que contida a aplicação do dispositivo à função de controle, o artigo proposto peca por transferir indevidamente ao julgador os ônus e as responsabilidades inerentes à atividade do gestor público (BRASIL, 2018b, p. 4). 
Prosseguiram-se as críticas lançadas pela PGR (BRASIL, 2018b, p. 5), suscitando, ademais, que não caberia ao julgador - substituindo-se ao gestor - delimitar medidas ou alternativas porventura incidentes quando de seu julgamento, tendo enquanto impensável "supor que o magistrado ou o órgão controlador possa analisar o exame das 'alternativas possíveis"”.

Assemelhadas críticas se prostraram lançadas no parecer do Tribunal de Contas da União (BRASIL, 2018c, p. 14-16), que, não obstante, procedeu a relevante complemento em sua motivação, anotando que o Código de Processo Civil, notadamente em seu artigo 489, $\S \S 1^{\circ}, 2^{\circ}$ e $3^{\circ}$, já estaria a abarcar os elementos de segurança à tutela decisória dos órgãos controladores, além do que, da hermenêutica do parágrafo único do art. 20 da "nova" LINDB, não se depreenderia serena interpretação quanto à avaliação das possíveis alternativas, pelo julgador, que dos autos constem, com vistas a se acautelar da exegese que porventura compreenda que deveria ele, o julgador, buscar a avaliação, per si, das "possíveis alternativas".

Noutravia, relevante mencionar terem juristas (MARQUES NETO et al., 2018, p. 3-4) sustentado mediante carta intitulada "Resposta aos comentários tecidos pela Consultoria Jurídica do TCU ao PL n. ${ }^{\circ} 7.448 / 2017$ ”, que a experiência demonstra que decisões de cunho concreto por vezes se balizam em valores jurídicos de cunho abstrato - "tais como o interesse público, o princípio da economicidade, a moralidade administrativa, etc.” (MARQUES NETO, 2017, p. 3), de forma que está o dispositivo a reforçar a ideia de responsabilidade decisória, não se tratando de substituição do gestor pelo julgador, mas sim que este último, ao se valer especialmente de comandos normativos abstratos, tenha em mente - com base no que dos autos conste - as alternativas que existem, ou não, ao gestor, os impactos daí decorrentes e, pois, concretize o juízo com a responsabilidade decisória, conforme excerto que se destaca:

O PL n ${ }^{\circ} 7.448 / 2017$ pretende inserir o artigo 20 na LINDB com a finalidade de reforçar a ideia de responsabilidade decisória estatal diante da incidência de normas jurídicas indeterminadas, as quais sabidamente admitem diversas hipóteses interpretativas e, portanto, mais de uma solução. A experiência demonstra ser comum a tomada de decisões muito concretas a partir de valores jurídicos bem abstratos — tais como o interesse público, o princípio da economicidade, a moralidade administrativa, etc. $\mathrm{O}$ fenômeno é comum às esferas administrativa, controladora e judicial. Diante desse quadro, o parágrafo único do art. 20 propõe instituir ao tomador de decisão o dever de demonstrar, via motivação, 'a necessidade e a adequação da medida imposta ou da invalidação de ato, contrato, ajuste, processo ou norma administrativa, inclusive em face das possiveis alternativas'.

[...] O dispositivo não exige conhecimento extra processual do julgador, mas sim que concretize sua função pública com responsabilidade. Veda, assim, motivações decisórias vazias, apenas retóricas ou principiológicas, sem análise prévia de fatos e de impactos. Obriga o julgador a avaliar, na motivação, a partir de elementos idôneos coligidos no processo administrativo, judicial ou de controle, as consequências práticas de sua decisão. E, claro, esse dever se torna ainda mais importante quando há pluralidade de alternativas. Quem decide não pode ser voluntarista, usar meras intuições, improvisar ou se limitar a invocar fórmulas gerais como 'interesse público', 'princípio da moralidade' e outras. É preciso, 
com base em dados trazidos ao processo decisório, analisar problemas, opções e consequências reais. Afinal, as decisões estatais de qualquer seara produzem efeitos práticos no mundo e não apenas no plano das ideias.

No mais, o dispositivo a ser inserido na LINDB é clara aplicação do conhecido princípio da proporcionalidade, que exige ao tomador de decisão a comprovação de que a medida a ser adotada é adequada, necessária e proporcional em sentido estrito. [...] (MARQUES NETO, 2017, p. 3-4).

Quer-nos parecer, de fato, que o dito art. 20 não obstaculiza decisão que possua em sua fundamentação - e até enquanto precípua motivação - a menção a princípios, sequer veda que assim se proceda, apenas consignando que ao fazê-lo deve se considerar as "consequências práticas da decisão", procedendo apenas se "adequado" e "necessário" inclusive, se o caso, face às "alternativas existentes".

Não devem, então, serem olvidados os reflexos da decisão quanto aos interesses da coletividade, continuidade da prestação do serviço público e formação de precedente para hipóteses análogas (dentre outras consequências que do caso se avizinhem), tampouco a exteriorização da ponderação levada a efeito para se concluir pela adequação e necessidade da decisão.

Tem-se enquanto lógico que a partir do momento em que a autoridade dotada de poderes decisórios de revisão, seja jurisdicional ou administrativa, ingressa no mérito de ato administrativo para decidir com base em valores jurídicos abstratos - que, ao seu ver, merecem "ponderação" distinta daquela realizada na decisão objeto de controle -, minimamente deve considerar também alternativas distintas (existentes ou não), até porque impossível (ao menos se de forma responsável) seria bem exercer juízo substitutivo (controlador) sem ponderar sobre as alternativas que tinha o prolator originário do ato objeto de controle.

Dos escritos de Kennedy e Fisher III (2006 apud BARROSO, 2015, p. 62) se extrai observação pertinente:

Como David Kennedy e Wiilian W. Fisher têm escrito, se tornou senso comum afirmar que os "materiais jurídicos não produzem soluções únicas para os casos individuais", que o trabalho jurídico não era sempre dedutivo, mas também "envolvia em grande medida a formulação de políticas", e que os juristas têm que "falar e pensar sobre consequências, ética, estatísticas e assim por diante".

Importante se faz sublinhar que a matéria versada no art. 20 do diploma em apreço não se confunde - embora também não seja antagônico - ao disposto no art. 489 do Novo Código de Processo Civil, isto pois no primeiro não se está a falar de elementos obrigatórios da sentença, mas sim de delimitação do juízo decisório, de forma que este passe a abarcar as consequências práticas da decisão quando de juízos fundamentados em valores jurídicos abstratos, bem como que, em o fazendo, considere a adequação e a necessidade da medida face as alternativas possíveis, estas últimas, por evidente, que dos autos constem ou deles possam se extrair.

A delimitação do juízo decisório aos fatos e fundamentos do processo - não se tratando, pois, de demandar do intérprete atividade prospectiva idem a do gestor - consta bem expressada nos arts. 
$3^{\mathrm{o}}, \S 2^{\mathrm{o}}, \mathrm{e} 4^{\mathrm{o}}, \S 1^{\mathrm{o}}$, do Decreto regulamentador.

Trata-se, pois e nosso ver, de exegese que complementa o disposto no Codex Processual, não estando nele exaurido, tampouco a ele desarmônico, constituindo interpretação bem mais ampla pois não se refere "apenas" aos fundamentos da decisão, mas à delimitação do objeto dela, com influxo, pois, em todo o sistema normativo publicista.

\section{DA OBSERVÂNCIA DA MOTIVAÇÃO E DA REALIDADE NO EXERCÍCIO DO JUÍZO SOBRE ATOS ADMINISTRATIVOS}

Por conseguinte, está a estampar a LINDB, em sua nova feição, dispositivos normativos específicos que suscitam a necessidade de que as decisões que decretem invalidade de ato indiquem as consequências de tal decreto, com equânime exposição de seus efeitos nos interesses sob crivo (art. 21, parágrafo único), consideração das dificuldades reais do gestor e as circunstâncias envolvidas no ato quando de juízos de invalidação ou sancionamento (art. 22 e seus $\S$ ), estabelecimento de regime de transição quando de decisões que imponham novo dever (art. 23) e a consideração das orientações gerais da época quando da ulterior revisão da juridicidade dos atos sub examine. Vem se reconhecendo que o disposto no art. 21 reforça o dever de motivação ${ }^{7}(v$. arts 93, IX, e 129, VIII, da Constituição da República) dos atos decisórios (MAFFINI, HEINEN, 2018, p. 2526), tendo percebido crítica por sua generalidade (BRASIL, 2018b, p. 6) mas anotando percepção de sua pertinência pela Comissão de Constituição e Justiça da Câmara dos Deputados (CÂMARA DOS DEPUTADOS, 2017), ao anotar que caminhamos "para ter decisões devidamente motivadas, com o detalhamento e a especificidade necessárias, de modo a não restarem dúvidas do respeito do seu conteúdo à legalidade e à proporcionalidade" (CÂMARA DOS DEPUTADOS, 2017, p. 9). A escorreita motivação da decisão administrativa - que dirá da jurisdicional - se constitui, aliás, em faceta do próprio princípio da publicidade consagrado enquanto norteador da Administração Pública (art. 37, caput, Constituição Federal):

Pela motivação o administrador público justifica sua ação administrativa, indicando os fatos (pressupostos de fato) que ensejam o ato e os preceitos jurídicos (pressupostos de direito) que autorizam sua prática. [...] A motivação, portanto, deve apontar a causa e os elementos determinantes da prática do ato administrativo, bem como o dispositivo legal em que se funda (MEIRELLES, 2012, p. 107).

Raras seriam as circunstâncias pelas quais se reconheceria impertinência em se demandar que eventual juízo invalidatório consigne as consequências de sua decisão, tampouco que sejam estas proporcionais, equânimes e não anormais ou excessivas, parecendo-nos novo aclamo dos precitados princípios da razoabilidade e da proporcionalidade.

Destaca-se que o disposto nos artigos 22, 23 e 24 da "nova" LINDB, vem sendo reconhecido a título de juridicização do "princípio da realidade" aos atos de controle da Administração Pública: 7 Note-se que a "motivação" compõe 04 (quatro) dos títulos do Decreto Federal n. ${ }^{\circ}$ 9.830/2019 (BRASIL, 2019). 
A publicação recente da Lei 13.655/2018, que alterou a Lei de Introdução às Normas do Direito Brasileiro, implicou consequências diretas na forma de atuar de magistrados, ministros, desembargadores e conselheiros. É que, por exemplo, a simples motivação legal para aplicação de sanções, sem considerar as circunstâncias fáticas que motivam uma conduta, não mais atende à fundamentação como comando constitucional previsto no artigo 93, incisos IX e X, da Constituição.

Hoje, mais do que antes, de suma importância que a motivação daqueles que julgam ou controlam os atos jurídicos, leve em conta as circunstâncias fáticas do caso concreto, bem como àquelas envoltas à figura do próprio agente que praticou a conduta, pois só assim, teremos julgamentos consentâneos com a realidade. (PIRONTI, 2018, p. 1).

No estudo de caso procedido por Pironti (2018, p. 1-2) - hipótese em que uma servidora pública (no exercício da atribuição de pregoeira em licitação pública) teve sua sanção afastada pelo Tribunal de Contas da União em virtude da reconhecida dificuldade imposta a ela em deter ciência quanto à impropriedade da conduta que há anos era praticada no órgão em que lotada sem parecer jurídico ou orientação superior que a desfizesse, mantendo, no caso, a decisão sancionatória apenas contra seu superior hierárquico -, é relevante se compreender como a LINDB foi utilizada enquanto fundamento normativo para decisão mais relevantemente motivada, tendo, ao se apreciar a conduta de agente público, considerado, de fato, as circunstâncias em que ela se dava e as alternativas médias de que dispunha (ou não) o sujeito, em firme aplicação do art. 22, que ao revés de afastar qualquer competência controladora, trouxe a ela maior coerência.

Por evidente que à boa exegese há de se considerar que se passe a ter, quando do cotejo da atuação administrativa, a consideração dos "obstáculos e as dificuldades reais do gestor e as exigências das políticas públicas a seu cargo, sem prejuízo dos direitos dos administrados" (art. 22, caput, LINDB), o que não significa, ao nosso ver, que estes valores passem a possuir relevo superior às normas postas de matriz constitucional (de ordem fiscal, orçamentária, etc.) - o que se afirma à luz da pertinente crítica de Nohara (2016, p. 7) quanto a dita desnecessidade da nova norma (pois o primado da realidade já estaria integrado na exegese jurídica), ineficácia (face o seu grau de abstratividade) e perigo (se for utilizada como brecha capciosa para descumprimento de exigências legais) -, mas que, notadamente quando do cotejo sancionatório e de invalidade estampado nos parágrafos deste dispositivo, não se olvide da realidade vivenciada pelo gestor.

Neste sentido o recente precedente do E. Tribunal de Contas do Estado de São Paulo (SÃO PAULO, 2018, p. 11), nos autos do TC n. ${ }^{\circ}$ 015743/989/18 e sob Relatoria do Conselheiro Sidney Estanislau Beraldo, em que se afirmou, com menção expressa ao art. 22 da LINDB, que aditamento levado à efeito em contrato administrativo mereceria juízo de regularidade, isto porque "houve a demonstração efetiva das dificuldades reais que impuseram a ação do agente para uma remodelação da direção inicialmente pretendida (nos ditames do artigo 22 da Lei de Introdução às Normas do Direito Brasileiro)."

A realidade de gestão, a pertinência de sua consideração e as consequências das decisões de 
controle perceberam oportuna menção no Decreto n. . 9.830/19 quanto a "modulação" de efeitos das decisões anulatórias, que deverão indicar as condições para que a regularização ocorra de forma proporcional e equânime e sem prejuízo aos interesses gerais ( $\operatorname{art.} 4^{\circ}, \S 3^{\circ}$ ), de forma a buscar a mitigação dos ônus ou das perdas dos administrados ou da administração pública que sejam anormais ou excessivos em função das peculiaridades do caso (art. $4^{\circ}, \S 5^{\circ}$ ) (BRASIL, 2019).

Mesmo raciocínio lógico jurídico está a se emanar tanto da necessidade de se considerarem novas ordens porventura dadas pelos órgãos de controle e/ou a mudança de suas orientações gerais (jurisprudências, súmulas, instruções normativas, etc.) enquanto merecedoras de considerações seja de regime jurídico de transição seja de juízo face às orientações da época (arts. 23 e 24 da LINDB e $6^{\circ}$ e $7^{\circ}$ do Decreto Federal n. ${ }^{\circ}$ 9.830/2019).

Isto pois, embora não se ignore que os juízos de controle por vezes emanam decisões de cunho técnico declaratório - isto é, reconhecem realidade normativa preexistente (BRASIL, 2018b, p. 7) -, não se deve mesmo olvidar que a ciência jurídica - também o sendo o planejamento gestor típico da atuação administrativa - é humana e, como tal, sujeita à volatilidade intrínseca à sua interpretação e exegese.

De fato improvável se considerar que não há modificações de entendimentos firmes de órgãos de controle (inclusive jurisdicionais) que infirmam direitos outrora tidos como consolidados, não sendo nada incomum já se proceder à regulamentação de efeitos de tutelas modificativas - vide, neste sentido, art. 927, $\S 2^{\circ}, 3^{\circ}$ e $4^{\circ}$, do N.CPC -, notadamente quando com influxo geral, à luz, inclusive, das assertivas procedidas pela Comissão de Constituição e Justiça da Câmara dos Deputados (2017, p. 10):

É nesse sentido, portanto, em respeito à segurança jurídica e aos próprios princípios da lealdade e da boa-fé, que se trouxe no projeto a necessidade de sempre se estabelecer uma transição em caso de mudança de interpretação, mesmo que não haja regime previamente estabelecido, permitindo-se que, a partir do diálogo entre o interessado e a autoridade prolatora da decisão definidora de nova orientação, seja negociada a referida transição, com a celebração de um compromisso para o ajustamento.

Nada impede, ademais, que decisões de controle porventura procedidas sobre atos não respaldados por considerações gerais vigentes à época deixem de sofrer decorrente influxo pelos dispositivos normativos indicados, o que nada se confunde com o dever de, em existindo tais orientações consideráveis à época pelo gestor, sejam elas - em coerência, proporcionalidade, razoabilidade e à luz do princípio da realidade - tomadas devidamente a tomo pelo intérprete controlador.

\section{DOS ACORDOS E CONSENSUALISMO NA ADMINISTRAÇÃO PÚBLICA}

Sustenta-se ter a nova LINDB consagrado permissivos à consensualidade na Administração Pública, 
acatando a celebração de compromisso com interessados com vistas a eliminar irregularidades ou situações contenciosas, observada a legislação aplicável (art. 26 e seus §§), estabelecendo previsão normativa à incidência da compensação quando de atos de controle, inclusive com compromisso entre os envolvidos (art. 27 e seus $\S \S$ ), e expressa normativa a permitir consultas públicas antes da edição de atos normativos (art. 29).

Não se ignora o enraizamento na cultura jurídico-administrativa nacional da sempre atuação contenciosa ou "vinculada" quando de controle ou aferição de condutas - públicas ou privadas desconformes à melhor subsunção normativa ${ }^{8}$, embora tampouco se olvide o reconhecimento de que tal exegese se mostra inapropriada para a eficiente ${ }^{9}$ e boa administração diante da complexa, volátil, ágil e tecnológica relação jurídica tipicamente moderna, cada vez mais se socorrendo a Administração Pública e os distintos órgãos e poderes que a compõem de mecanismos de consensualidade e acordos com vistas ao atingimento razoável e dinâmico dos fins recíprocos:

O recurso ao clássico esquema de atuação administrativa por meio de atos administrativos unilaterais, cunhados no exercício da prerrogativa imperativa, parece não mais dar conta do satisfatório exercício dos atuais deveres cometidos à Administração Pública. A complexidade do atual direito administrativo coloca em xeque respostas binárias do tipo "proibido/permitido" a algumas situações concretas, como nos casos de conflito entre Administração Pública e administrado, as quais poderiam ser mais bem conformadas com acordos que valorizem decisões mais consentâneas às especificidades do caso e, assim, mais eficientes. Ademais, a configuração do Estado Democrático enseja a participação do administrado no desenvolvimento das atividades administrativas - fator que propicia a ascensão da consensualidade. (PALMA, 2015, p. 25-26).

Esta consensual maneira de atuação da Administração Pública também não se mostra desarmônica a diversos diplomas normativos vigentes que preveem análogas circunstâncias, parecendo-nos merecer citação a aplicação já expressa da arbitragem no âmbito da Administração Pública (art. $1^{\circ}$, $\S 1^{\circ}$, Lei Federal n. ${ }^{\circ}$ 9.307/1996), acordos de leniência no âmbito do CADE (arts. 86 e ss. da Lei Federal n. ${ }^{\circ}$ 12.529/2011) e em atos de corrupção (art. 16 da Lei Federal n. ${ }^{\circ}$ 12.846/2013), assim

8 "Dever de sancionar. Registre-se, por último, que, uma vez identificada a ocorrência de infração administrativa, a autoridade não pode deixar de aplicar a sanção. Com efeito, há um dever de sancionar, e não uma possibilidade discricionária de praticar ou não tal ato. A doutrina brasileira, mesmo em obras gerais, costuma enfatizar tal fato em relação ao dever disciplinar [...], mas o dever de sancionar tanto existe em relação às infrações internas quanto em relação às externas." (MELLO, 2019, p. 915).

"O âmbito de discricionariedade na aplicação de sanções em contratos administrativos não faculta ao gestor, verificada a inadimplência injustificada da contratada, simplesmente abster-se de aplicar-lhe as medidas previstas em lei, mas sopesar a gravidade dos fatos e os motivos da não execução para escolher uma das penas exigidas nos artigos 86 e 87 da Lei 8.666/1993, observado o devido processo legal." (BRASIL, 2006).

"Uma vez interpretada as normas jurídicas, o agente público as aplicará, de acordo com o fato concreto, em vista do interesse público que lhe cabe proteger. No caso de penalidades administrativas, ocorre a imposição delas, isto é, a autoridade administrativa declara a direta e imediata consequência jurídica cominada ao infrator ou responsável." (VITTA, 2018, p. 1).

9 "Isso quer dizer, em suma, que a eficiência administrativa se obtém pelo melhor emprego dos recursos e meios (humanos, materiais e institucionais) para melhor satisfazer às necessidades coletivas num regime de igualdade dos usuários. Logo, o princípio da eficiência administrativa consiste na organização racional dos meios e recursos humanos, materiais e institucionais para a prestação de serviços públicos de qualidade com razoável rapidez, consoante previsão do inciso LXXVIII do art. $5^{\circ}$ (EC-45/2004) e em condições econômicas de igualdade dos consumidores." (SILVA, 2013, p. 676). 
como o já consolidado permissivo normativo aos intitulados Termos de Ajustamento de Conduta (art. 5º,$\S 6^{\circ}$, Lei Federal n. ${ }^{\circ} 7.347 / 1985$ ).

Até mesmo no âmbito do Direito Penal - em que passível seria de maiores críticas face à severa indisponibilidade, em tese, dos valores envolvidos - os acordos de colaboração premiada tomam as manchetes jornalísticas diariamente.

Evidencia-se sobremaneira que a previsão normativa geral a propiciar, conforme o caso e "observada a legislação aplicável", compromissos com vistas à coerente, consensual e paulatina regularização de relações jurídicas pode vir a se tornar instrumento jurídico de relevante atuação administrativa para acautelar situações de permanente irregularidade que apenas fazem somar deletérios efeitos socioeconômicos e ambientais, por vezes merecedores de soluções graduais. A síntese processada por Marques Neto e Freitas (2018, p. 4) em seu artigo intitulado "O art. 26 da LINDB e o consenso na função de polícia administrativa"- cuja leitura é indispensável -, é merecedora de destaque:

[...] A Lei 13.655/2018, diferentemente do que ela foi acusada, não tem o desiderato de fomentar ilicitudes, ou de tornar o controle mais lasso. Muito ao revés, o racional na nova lei — do qual é saliente o seu artigo 26 que ora se comenta - é o de conferir transparência às relações público-privadas. A história demostrou que o arbítrio e a unilateralidade do exercício do poder extroverso, em vez de reprimir, fomentaram a prática de ilegalidades.

Consagrou a nefasta lógica do "criar dificuldades, para vender facilidades".

A Lei 13.655/2018 caminha no sentido oposto; processualiza e confere transparência ao consenso. É um novo caminho para os próximos anos da história sobre o exercício da função de polícia.

Faz-se oportuno anotar a preponderância da eficiência da consensualidade estampada nos arts. 26 e 27 da LINDB perante o fato de que os próprios dispositivos concedem razoável "contrapeso" típico do sistema normativo, demandando "motivação" e expondo a "vedação à exoneração permanente" (art. 26, $\S 1^{\circ}$, I e III, e art. 27, $\S 1^{\circ}$ ), submetendo-se os ajustes e acordos a níveis de controle, tais como os demais institutos da espécie, que, como dito, não é nova nem à Administração Pública nem às próprias competências dos órgãos de controle (MARQUES NETO, FREITAS, 2018, p. 2-3).

O Decreto Federal n. ${ }^{\circ}$ 9.830/2019 - no exercício regulamentar para dar “fiel execução" à lei (art. 84, IV, CF) - também clamou por transparente motivação na decisão de celebrar compromisso (arts. $9^{\circ}, \S 2^{\circ}$, e $10, \S 1^{\circ}$ ), com relevante fixação de aspectos da instrução do processo administrativo, dependente de oitiva do órgão jurídico, realização de consultas públicas (quando cabíveis), aferição de razões de relevante interesse geral, bem como tomada de parecer técnico conclusivo sobre a viabilidade técnica, operacional e, quando for o caso, sobre as obrigações orçamentário-financeiras a serem assumidas (art. 10, I, II, III, § $4^{\circ}$, I e II).

A regulamentação também estampou a possibilidade de celebração de ajuste consensual entre gestores e órgãos de controle interno, "com a finalidade de corrigir falhas apontadas em ações de controle, aprimorar procedimentos, assegurar a continuidade da execução do objeto, sempre que 
possível, e garantir o atendimento do interesse geral", ressalvando o descabimento deste para elidir reflexos jurídicos quanto a eventual dano ao erário provocado por agente mediante conduta dolosa ou em erro grosseiro (art. $11, \S 2^{\circ}$ ).

Frise-se, por oportuno, que na toada participativa do administrado é que se depreende a permissão à consulta pública antes da edição de atos normativos (art. 29), concedendo ferramenta aos mais variados níveis de gestão, mormente porque consagra relevante instrumento de "participação democrática" - que é núcleo essencial do regime jurídico vigente (art. $1^{\circ}$, caput, $\mathrm{V}$, parágrafo único, dentre outros dispositivos da Constituição da República) -, além de conferir notável publicidade aos atos (ou pretensos atos) estatais, a teor de referido princípio também consagrado enquanto incidente na Administração Pública (art. 37, caput, CF) (SILVA, 2013, p. 673-674).

Convém assinalar que a obrigatoriedade de consultas ou audiências públicas já se impregna em determinadas matérias legislativas (tais como nas orçamentárias anuais e plurianuais do Poder Executivo $^{10}$ ), prestando-se enquanto relevante engrandecedor o permissivo a que assim se proceda sempre que pertinente, ainda mais em se considerando o direito subjetivo do administrado a que sua contribuição em referida consulta pública seja efetivamente objeto da decisão (parte final do art. 29), muito contribuindo à maturidade democrática e normativa (RIGAMONTI, 2020).

\section{DO SANCIONAMENTO A AGENTES PÚBLICOS}

A LINDB previu, notadamente nos $\S \S 1^{\circ}, 2^{\circ}$ e $3^{\circ}$, do art. 22 e em seu art. 28, critérios norteadores e delimitadores das hipóteses abstratas em que a invalidade do ato administrativo ou o irregular exercício das atribuições legais do cargo venha a provocar sancionamento pessoal ao servidor público.

Trata-se, como sobredito no capítulo $2^{\circ}$ e notadamente nos parágrafos do aludido art. 22 , do influxo normativo do princípio da realidade tanto às hipóteses de invalidação de atos administrativos quanto nas de sancionamento de agentes públicos, de forma a considerá-lo quando das decisões de controle (administrativas ou jurisdicionais) que venham a reconhecer pessoal responsabilidade. Ademais, robusta e firme assertiva passa a constar no caput do art. 28, ao anotar que "O agente público responderá pessoalmente por suas decisões ou opiniões técnicas em caso de dolo ou erro grosseiro".

Temos que está o legislador a consagrar a necessidade de voluntariedade quando da incursão do agente em determinada infração de ordem civil ou administrativa. Isto pois é cediço que, em rigor, as sanções administrativas se constituem em inquestionável instrumento de regularização de condutas sociais, a fazer se concluir ter o Direito Administrativo repressivo núcleo principiológico que se confunde com o do próprio Direito Penal (JUSTEN FILHO, 2012, p. 1.008; MOREIRA NETO, GARCIA, 2012), não passando despercebida a anotação de Mello (2019, p. 898) no sentido de que o que distingue a sanção administrativa da penal é "apenas" a autoridade que a declara,

10 Vide arts. $9^{\circ}, \S 4^{\circ}$, e $48, \S 1^{\circ}$, I, da Lei Complementar n. ${ }^{\circ} 101 / 2000$ - Lei de Responsabilidade Fiscal. (BRASIL, 2000, p. 4, 17-18). 
sendo na primeira a administrativa e na segunda a jurisdicional.

Não há como se questionar a afirmação, pois, de que a sanção administrativa corresponde a instrumento de coerção educativa a quem cometera, voluntariamente, sua respectiva e antecedente infração. É remédio jurídico que se presta, tal qual na esfera penal, a satisfazer a necessidade coletiva mediante inibição de condutas reconhecidas como degradantes em determinada coletividade, à sua época:

A configuração de infrações pressupõe a reprovabilidade da conduta do particular. Isso significa que a infração se caracterizará pelo descumprimento aos deveres legais ou contratuais, que configure materialização de um posicionamento subjetivo reprovável. Como decorrência, a imposição de qualquer sanção administrativa pressupõe o elemento subjetivo da culpabilidade. No Direito Penal democrático não há responsabilidade penal objetiva - ainda quando se possa produzir a objetivação da culpabilidade. Mas é essencial e indispensável verificar a existência de uma conduta interna reprovável. Não se pune alguém em virtude da mera ocorrência de um evento material indesejável, mas se lhe impõe uma sanção porque atuou de modo reprovável. As palavras de Welzel refletem concepção que não comporta reparos, quando afirmou que "O direito não pode proibir a causação de um determinado resultado, senão que apenas a realização de ações dirigidas ou que levem consigo a possibilidade (perigo) da lesão do bem jurídico [...] O injusto criminal somente resulta plenamente constituído, ao meu ver, quando ao desvalor da ação se agrega o desvalor do resultado.” E acrescentou que quando se produz a lesão a um bem jurídico sem que tal se configure como resultado de uma ação ou omissão reprovável de um sujeito, tratar-se-á de "uma desgraça mas não de um injusto". (JUSTEN FILHO, 2012, p. 1.012).

Cientes de que o Estado apenas goza de poderes indispensavelmente instrumentais à satisfação de seus deveres, não haveria como considerar nexo de pertinência lógica em se sancionar aquele que porventura infringiu determinada norma sem sê-lo voluntariamente (MELLO, 2019, p. 898900) ou cuja culpa, crassa, revele assunção dos riscos de fazê-lo, tanto que Mello (2019, p. 906) reconhece o principio da exigência de voluntariedade enquanto norteador da atuação sancionatória estatal:

Princípio da exigência de voluntariedade para incursão na infração - $\mathrm{O}$ Direito propõe-se a oferecer às pessoas uma garantia de segurança, assentada na previsibilidade de que certas condutas podem ou devem ser praticadas e suscitam dados efeitos, ao passo que outras não podem sê-lo, acarretando consequências diversas, gravosas para quem nela incorrer. Donde, é de meridiana evidência que descaberia qualificar alguém como incurso em infração quando inexista a possibilidade de prévia ciência e prévia eleição, in concreto, do comportamento que o livraria da incidência na infração e, pois, na sujeição às sanções para tal caso previstas.

A modificação legislativa em epígrafe, malgrado esteja a abarcar doutrina especializada consolidada, nem por isto se torna despicienda, mormente porque traz influxo relevante na atuação 
de controle, informando que do conceito de culpa - reconhecida no art. $37 \S 6^{\circ}$, da Constituição Federal, enquanto compatível à responsabilidade civil do agente público - se extrai apenas a culpa "grave" ("elevado grau de negligência, imprudência ou imperícia" - v. art. $12, \S \S 1^{\circ}, 2^{\circ} 3^{\circ}, 4^{\circ}$ e $5^{\circ}$, do Decreto n. ${ }^{\circ}$ 9.830/19), excluídas, pois, a leve e a levíssima, não estando estas últimas olvidadas ordinariamente do regime da responsabilidade civil ${ }^{11}$, daí a pertinência de, em o fazendo quanto aos agentes públicos, o seja expressamente.

Apropriado, ainda, consignar-se que a Comissão de Constituição e Justiça (CÂMARA DOS DEPUTADOS, 2017) bem observou que referida disposição normativa estava a acatar a jurisprudência já dominante, de certo que as críticas da Procuradoria Geral da República (BRASIL, 2018 b, p. 11-12) mais focaram os parágrafos do aludido art. 28, resolvidos, pois, pelos vetos presidenciais, mantidos quando da promulgação do diploma normativo.

Não se olvidando que a atuação administrativa se envolve comumente com a solução de casos complexos, de variáveis imprevisíveis e com influxo de interesses os mais distintos e relevantes (políticos, econômicos, sociais, etc.) - cuja complexidade e prerrogativas políticas (ou de função) deverão ser consideradas em eventual responsabilização (arts. 12, $4^{\circ}$, e 13, caput, Decreto 9.830/19) -, tem-se enquanto razoável a previsão legislativa condicionante da responsabilidade civil às hipóteses de ser a conduta infratora ou dolosa ou, se culposa, que o seja apenas quando grave (erro grosseiro), acautelando exageros e desproporcionalidades na perquirição de ilícitos administrativos.

Considerar o erro não grosseiro enquanto suficiente para o sancionamento pessoal do agente público seria fazer de todas as autoridades coatoras em mandados de segurança (e apenas enquanto exemplo) quando neles sucumbentes tornarem-se automática e pessoalmente responsáveis pelos danos porventura ocasionados ${ }^{12}$.

O Decreto Federal n. ${ }^{\circ}$ 9.830/19 trouxe as anotações relevantes de que o erro grosseiro ou dolo do emitente de opinião técnica ou de inferior hierárquico não abarca, ao menos não automaticamente, a autoridade que o acata ou que lhe é superior, respectivamente, condicionada sua responsabilidade à existência de elementos que lhe propiciassem aferir o erro ou dolo da antecedente manifestação ou de seu inferior hierárquico (art. $12, \S \S 6^{\circ}$ e $7^{\circ}$ ).

Neste ínterim, o art. 28 da LINDB vem a pacificar a possibilidade de agentes públicos virem a ser responsabilizados, inclusive, por emanações técnicas, excluindo a tecnicidade do ato administrativo enquanto manto a lhe impedir a atuação controladora, à luz do quanto - embora não de maneira uníssona - já se vê na jurisprudência:

11 "Culpa lata ou grave: imprópria ao comum dos homens e a modalidade que mais se avizinha do dolo; culpa leve: falta evitável com atenção ordinária; culpa levíssima: falta só evitável com atenção extraordinária ou com especial habilidade. A culpa grave ao dolo se equipara (culpa lata dolus equiparatur). Assim, se em determinado dispositivo legal constar a responsabilidade do agente por dolo, deve-se entender que também responde por culpa grave (CC, art. 392). No cível, a culpa mesmo levíssima obriga a indenizar (in lege Aquilia et levíssima culpa venit)." (GONÇALVES, 2012, p. 505).

12 Recomenda-se, a expor o reflexo deletério do receio exacerbado - face eventual responsabilização - em tomadas de decisões administrativas em casos complexos, a breve reportagem: "O apagão de canetas dos agentes públicos." (RITTNER, 2018). 
CONSTITUCIONAL. ADMINISTRATIVO. TRIBUNAL DE CONTAS. TOMADA DE CONTAS: ADVOGADO. PROCURADOR: PARECER. C.F., art. 70, parág. único, art. 71, II, art. 133. Lei $\mathrm{n}^{\circ} 8.906$, de 1994, art. $2^{\circ}, \S 3^{\circ}$, art. $7^{\circ}$, art. 32 , art. 34, IX. I. - Advogado de empresa estatal que, chamado a opinar, oferece parecer sugerindo contratação direta, sem licitação, mediante interpretação da lei das licitações. Pretensão do Tribunal de Contas da União em responsabilizar o advogado solidariamente com o administrador que decidiu pela contratação direta: impossibilidade, dado que o parecer não é ato administrativo, sendo, quando muito, ato de administração consultiva, que visa a informar, elucidar, sugerir providências administrativas a serem estabelecidas nos atos de administração ativa. [...] II. - O advogado somente será civilmente responsável pelos danos causados a seus clientes ou a terceiros, se decorrentes de erro grave, inescusável, ou de ato ou omissão praticado com culpa, em sentido largo: Cód. Civil, art. 159; Lei 8.906/94, art. 32. III. - Mandado de Segurança deferido (BRASIL, 2003).

Ademais, o Decreto n. ${ }^{\circ}$ 9.830/19 estampa (art. 14) que referida delimitação da responsabilidade civil às hipóteses de dolo e erro grosseiro abarca a ação de regresso da parte final do $\S 6^{\circ}$ do art. 37 da Constituição da República - o que, no mais, já de fato decorre do caput do art. 28 da LINDB -, estampando, não obstante, a oportuna ressalva de que não há tal delimitação extensiva às infrações e decorrentes sanções disciplinares, subsumidas às suas leis específicas e que não se confundem com responsabilidade civil, mas funcional, eventualmente suscetíveis de perquirição mediante culpa stricto sensu (art. 17).

Entende-se, portanto, que tendo os parágrafos do art. 28 da LINDB sido objeto de veto presidencial, mantido na Casa Legislativa, de fato o que seu caput revela é a segurança jurídica face ao influxo normativo nas decisões de controle sobre atos administrativos nas quais se revelem sanções aos agentes públicos que lhes exararam ou lhes informaram.

\section{CONSIDERAÇÕES FINAIS}

Depreende-se, da própria forma como se esforçaram a síntese e a contextualização das alterações recentes promovidas na LINDB, que, em rigor, elas vêm corroborar a segurança jurídica proveniente da relevantíssima atuação controladora quando do exercício de sua competência para decidir, sustar, invalidar ou sancionar, isto é, controlar, em geral, os órgãos da Administração Pública.

Dada a volatilidade da atuação administrativa, mormente face aos serviços públicos que a motivam - com todos os pormenores técnicos, tecnológicos, quantitativos e qualitativos -, faz-se, de fato, preambular que se fixe regime cada vez mais objetivo e uniforme na atuação de controle, inclusive com vistas ao aperfeiçoamento das condutas dos gestores e técnicos que se submetem à atuação controladora, dotados como serão, ao menos em tese, de maiores condições de percepção do regular e do irregular.

Não se olvide, ademais, que tomadas de decisão, especialmente em casos complexos, não se 
afiguram de todo simplistas, tal como não é a própria atuação controladora, sendo de se consignar, porém, que o órgão controlado é o que detém a competência “originária" de decidir e de solucionar a problemática pública que é posta à sua cura - quantas vezes inexistindo meios de consulta hábeis e concretos a seus controladores -, não detendo condição de, a posteriori, simplisticamente se submeter a julgamento acerca se o quanto decidido à época se mostrou o meio mais viável, ou não. Pertinente, pois, que o esforço de empatia jurídica determinado pela nova LINDB reflita nos juízos acerca da regularidade ou irregularidade dos atos sob controle, tornando mais uniformes as decisões correlatas, com os reflexos benéficos tanto na segurança jurídica do intérprete inicial quanto, com maior coesão, exercer-se mais firme atuação controladora, quiçá com condições mais resolutas de, prostrando-se a irregularidade patente, vir a tomar a conduta efetivamente proporcional.

A conclusão deste trabalho não pode deixar de citar o desfecho que o próprio legislador pretendeu com a inovação normativa objeto de estudo, tendo ele mesmo sintetizado teleologicamente o conjunto normativo produzido, ao asseverar que "As autoridades públicas devem atuar para aumentar a segurança jurídica na aplicação das normas" (art. 30, LINDB).

\section{REFERÊNCIAS}

ALEXY, Robert. Teoria dos direitos fundamentais. Tradução de Virgílio Afonso da Silva. 2. ed. São Paulo: Malheiros Editores, 2012.

ÁVILA, Humberto. Teoria dos princípios: da definição a aplicação dos princípios jurídicos. 10 . ed. São Paulo: Editora Malheiros, 2009.

BARROSO, Luís Roberto. A dignidade da pessoa humana no direito constitucional contemporâneo: a construção de um conceito jurídico à luz da jurisprudência mundial. Belo Horizonte: Ed. Fórum, 2015.

BRASIL. [Constituição (1988)]. Constituição da República Federativa do Brasil de 1988, Brasília, DF: Presidência da República, 1988. Disponível em: http://www.planalto.gov.br/ ccivil_03/constituicao/constituicao.htm. Acesso em: 29 set. 2018.

BRASIL. Decreto Federal n. ${ }^{\circ}$ 9.830, de 10 de junho de 2019. Regulamenta o disposto nos art. 20 ao art. 30 do Decreto-Lei n $^{\circ}$ 4.657, de 4 de setembro de 1942, que institui a Lei de Introdução às normas do Direito brasileiro. Diário Oficial da União: Seção 1, Brasília, DF, p. 4, 11 jun. 2019. Disponível em: https://www.lexml.gov.br/urn/urn:lex:br:federal:decreto:2019-06-10;9830. Acesso em: 29 set. 2018.

BRASIL. Decreto-Lei n. ${ }^{0}$ 4.657, de 04 de setembro de 1942. Lei de Introdução às normas do Direito Brasileiro. Rio de Janeiro: Presidência da República, 1942. Disponível em: http://www. planalto.gov.br/ccivil_03/decreto-lei/del4657.htm. Acesso em: 29 set. 2018.

BRASIL. Lei Complementar n. ${ }^{0}$ 101, de 04 de maio de 2000. Estabelece normas de finanças públicas voltadas para a responsabilidade na gestão fiscal e dá outras providências. Brasília, DF: Presidência da República, 2000. Disponível em: http://www.planalto.gov.br/ccivil 03/leis/lcp/ lcp101.htm. Acesso em: 29 set. 2018. 
BRASIL. Lei Federal n. ${ }^{\circ}$ 13.655, de 25 de abril de 2018. Inclui no Decreto-Lei no 4.657, de 4 de setembro de 1942 (Lei de Introdução às Normas do Direito Brasileiro), disposições sobre segurança jurídica e eficiência na criação e na aplicação do direito público. Diário Oficial da União: Seção 1, Brasília, DF, p. 1, 26 abr. 2018a.

BRASIL. Procuradoria Geral da República. Ofício n. ${ }^{\circ}$ 330/2018. Nota Técnica Conjunta n. ${ }^{\circ}$ 01/2018, de 13 de abril de 2018. Brasília, DF: Ministério Público Federal, 2018b. Disponível em: www.mpf.mp.br/pgr/documentos/Oficio_NotaTecnica_130418_PGR00192069_2018.pdf. Acesso em: 29 set. 2018.

BRASIL. Supremo Tribunal Federal. ADI's n. ${ }^{\text {ss }}$ 6421, 6422, 6424, 6425, 6427, 6428 e 6431 MC. Direito Administrativo. Ações diretas de Inconstitucionalidade. Responsabilidade civil e administrativa de agentes públicos. Atos relacionados à pandemia de covid-19. Relator: Min. Luís Roberto Barroso, 21 de maio de 2020. Disponível em: https://www.migalhas.com.br/ arquivos/2020/5/C8CE49A83E45F6_lrb.pdf. Acesso em: 1 set. 2018.

BRASIL. Supremo Tribunal Federal. MS n. ${ }^{\circ}$ 24.073/DF. Tribunal Pleno. Relator: Min. Carlos Velloso, DJ de 31 de outubro de 2003. Disponível em: https://stf.jusbrasil.com.br/ jurisprudencia/772349/mandado-de-seguranca-ms-24073-df. Acesso em: 1 set. 2018.

BRASIL. Tribunal de Contas da União. Acórdão no 2.558/2006. $2^{\text {a }}$ Câmara. Relator: Min. Walton Alencar Rodrigues, 12 de setembro de 2006. Disponível em: https://www.lexml.gov.br/ urn/urn:lex:br:tribunal.contas.uniao;camara.2:acordao:2006-09-12;2558. Acesso em: 1 set. 2018.

BRASIL. Tribunal de Contas da União. Parecer sobre o PL 7448/2017, em face do parecerresposta dos autores do PL e de outros juristas. TC n. ${ }^{\circ}$ 012.028/2018-5, Brasília, $2018 \mathrm{c}$. Disponível em: https:/cdn.oantagonista.net/uploads/2018/04/PL-7448-2017-Inteiro-teor-AlteraLINDB-Parecer-Conjur-2018-04-20.pdf. Acesso em: 29 set. 2018.

BRASIL. Tribunal de Contas da União. TCU promove três encontros para avaliar novas normas de controle da LINDB. Brasília: TCU, 2018d. Disponível em: https://portal.tcu.gov.br/ imprensa/noticias/tcu-promove-tres-encontros-para-avaliar-novas-normas-de-controle-da-lindb8A81881F631C32E60163289EC4233D34.htm. Acesso em: 31 ago. 2018

BULOS, Uadi Lammêgo. Constituição Federal Anotada. 10. ed. São Paulo: Editora Saraiva, 2012.

CÂMARA DOS DEPUTADOS. Projeto de Lei n. ${ }^{\mathbf{0}}$ 7.448-A, de 15 de setembro 2017. Brasília: Câmara Dos Deputados, 2017. Disponível em: https://www.camara.leg.br/proposicoesWeb/prop_ mostrarintegra?codteor=1614971. Acesso em: 1 set. 2018.

GONÇALVES, Carlos Roberto. Direito Civil, Vol. 01 - Parte Geral. 10. ed. São Paulo: Saraiva, 2012.

GUERRA FILHO, Willis Santiago. Processo Constitucional e Direitos Fundamentais. 5. ed. São Paulo: RCS Editora, 2007.

JUSTEN FILHO, Marçal. Comentários à Lei de Licitações e Contratos Administrativos. $15^{\circ}$ edição. São Paulo: Editora Dialética, 2012.

MAFFINI, Rafael; HEINEN, Juliano. Análise acerca da aplicação da Lei de Introdução às 
Normas do Direito Brasileiro (na redação dada pela Lei n. ${ }^{\circ}$ 13.655/2018) no que concerne à interpretação de normas de direito público: operações interpretativas e princípios gerais de direito administrativo. RDA - Revista de Direito Administrativo, Rio de Janeiro, v. 277, n. 3, p. 247-278, set./dez. 2018. Disponível em: http://bibliotecadigital.fgv.br/ojs/index.php/rda/ article/view/77683/74646. Acesso em: 2 ago. 2019.

MARQUES NETO, Floriano de Azevedo. Resposta aos comentários tecidos pela Consultoria Jurídica do TCU ao PL n ${ }^{\circ}$ 7.448/2017. 2017. Disponível em: https://www.conjur.com.br/dl/ parecer-juristas-rebatem-criticas.pdf. Acesso em: 15 set. 2018.

MARQUES NETO, Floriano de Azevedo; FREITAS, Rafael Véras de. O art. 26 da LINDB e o consenso da função de polícia administrativa. Disponível em: https://www.conjur.com. br/2018-jul-16/opiniao-lindb-consenso-funcao-policia-administrativa. Acesso em: 15 set. 2018.

MARTINES, Fernando. Sandálias da humildade: Ministros criticam juízes que decidem baseados na moralidade. 2018. Disponível em: https:/www.conjur.com.br/2018-set-17/ministroscriticam-juizes-decidem-baseados-moral. Acesso em: 24 set. 2018.

MARTINS, Ricardo Marcondes. Abuso de direito e a constitucionalização do direito privado. São Paulo: Editora Malheiros, 2010.

MEIRELLES, Hely Lopes. Direito administrativo Brasileiro. 38. ed. São Paulo: Editora Malheiros, 2012.

MELLO, Celso Antônio Bandeira de. Curso de Direito Administrativo. 34 edição, revista e atualizada até a Emenda Constitucional 99, de 14.12.2017. São Paulo: Malheiros Editores, 2019.

MOREIRA NETO, Diogo de Figueiredo; GARCIA, Flávio Amaral. A principiologia no direito administrativo sancionador. Revista Eletrônica de Direito Administrativo Econômico, Salvador, n. 28, nov./dez./jan. 2012. Disponível em: http://www.direitodoestado.com/revista/redae-28novembro-2011-diogo-figueiredo-flavio-garcia.pdf. Acesso em: 26 jan. 2016.

NOHARA, Irene. Proposta de alteração da LINDB (projeto 349/2015). 2016. Disponível em: https://direitoadm.com.br/proposta-de-alteracao-da-lindb-projeto-349-2015/. Acesso em: 29 set. 2018 .

OLIVEIRA, José Roberto Pimenta. Discricionariedade e razoabilidade. Revista Eletrônica de Direito da PUC-SP, São Paulo, v. 1, 2008. Disponível em: https://revistas.pucsp.br/index.php/ red/article/view/728/510. Acesso em: 29 set. 2018.

PALMA, Juliana Bonacorsi de. Sanção e acordo na administração pública. São Paulo: Malheiros Editores, 2015.

PIRONTI, Rodrigo. A LINDB e a jurisprudência do TCU: decisões coerentes e o princípio da realidade. Consultor Jurídico, São Paulo, ago. 2018. Disponível em: https://www.conjur.com. br/2018-ago-13/rodrigo-pirondi-lindb-tcu-principio-realidade. Acesso em: 15 set. 2018.

RIGAMONTI, Thiago Reis Augusto. Da participação pública na tomada de decisões de estado e de sua consideração na atuação decisória. In: COLETA, Daniel Dela (org.). MOURA, Grégore Moreira de (org.). Direito público: liberdade, igualdade e fraternidade visto por Maçons e Demolays. Belo Horizonte: Editora D’Plácido, 2020. p. 237-260. 
RITTNER, Daniel. O apagão de canetas dos agentes públicos. Valor Econômico, São Paulo, 27 jul. 2018. Disponível em: www.revistaferroviaria.com.br/index. asp?inCdEditoria=1\&InCdMateria=28379. Acesso em: 24 set. 2018.

SÃO PAULO. Tribunal de Contas do Estado. TC n. ${ }^{\circ}$ 015743/989/18. São Paulo, 2018. Relator: Cons. Sidney Estanislau Beraldo, 23 de outubro de 2018.

SILVA, José Afonso da. Curso de direito constitucional positivo. 36. ed. São Paulo: Editora Malheiros, 2013.

SILVA, Virgílio Afonso da. O proporcional e o razoável. Revista dos Tribunais, São Paulo, v. 798, p. 23-50, 2012.

SUNDFELD, Carlos Ari. Direito administrativo para céticos. 2. ed. São Paulo: Malheiros editores, 2014.

VITTA, Heraldo Garcia. Aspectos da imposição de penalidades administrativas. Âmbito Jurídico, Rio Grande, v. XI, n. 53, maio 2008. Disponível em: http://www.ambito-juridico.com. br/site/index.php?n_link=revista_artigos_leitura\&artigo_id=2644. Acesso em: 29 set. 2018.

Como citar: MIALHE, Jorge Luís; RIGAMONTI, Thiago Reis Augusto. As alterações na Lei de Introdução às Normas Do Direito Brasileiro e seu influxo no Direito Administrativo. Revista do Direito Público, Londrina, v. 16, n. 1, p. 97-118, abr. 2021. DOI: 10.5433/24157-108104-1.2021v1 6n1p. 97. ISSN: 1980-511X

Recebido em: 27/05/2019

Aprovado em: 24/08/2020 